\title{
Technosocial Modeling for Determining the Status and Nature of a State's Nuclear Activities
}

Zoe N. Gastelum

Julia Harvey

This report was prepared for the Office of International Regimes and Agreements (NA-243), Dunbar Lockwood, under WBS 24.3.2.13.8.

September 2009 


\title{
DISCLAIMER
}

This report was prepared as an account of work sponsored by an agency of the United States Government. Neither the United States Government nor any agency thereof, nor Battelle Memorial Institute, nor any of their employees, makes any warranty, express or implied, or assumes any legal liability or responsibility for the accuracy, completeness, or usefulness of any information, apparatus, product, or process disclosed, or represents that its use would not infringe privately owned rights. Reference herein to any specific commercial product, process, or service by trade name, trademark, manufacturer, or otherwise does not necessarily constitute or imply its endorsement, recommendation, or favoring by the United States Government or any agency thereof, or Battelle Memorial Institute. The views and opinions of authors expressed herein do not necessarily state or reflect those of the United States Government or any agency thereof.

\author{
PACIFIC NORTHWEST NATIONAL LABORATORY \\ operated by \\ BATTELLE \\ for the \\ UNITED STATES DEPARTMENT OF ENERGY \\ under Contract DE-AC05-76RL01830 \\ Printed in the United States of America \\ Available to DOE and DOE contractors from the \\ Office of Scientific and Technical Information, \\ P.O. Box 62, Oak Ridge, TN 37831-0062; \\ ph: (865) 576-8401 \\ fax: (865) 576-5728 \\ email: reports@adonis.osti.gov \\ Available to the public from the National Technical Information Service, \\ U.S. Department of Commerce, 5285 Port Royal Rd., Springfield, VA 22161 \\ ph: (800) 553-6847 \\ fax: (703) 605-6900 \\ email: orders@ntis.fedworld.gov \\ online ordering: http://www.ntis.gov/ordering.htm
}




\section{Technosocial Modeling for Determining the Status and Nature of a State's Nuclear Activities}

Zoe N. Gastelum ${ }^{1}$

Julia Harvey ${ }^{2}$

September 2009

Prepared for

the U.S. Department of Energy

under Contract DE-AC05-76RL01830

Pacific Northwest National Laboratory

Richland, Washington 99352

\footnotetext{
${ }^{1}$ Pacific Northwest National Laboratory

${ }^{2}$ University of Texas - Austin (NA-243 Safeguards Intern, Summer 2009)
} 



\section{Executive Summary}

In support of the development of the technical report, "The International Atomic Energy Agency State Evaluation Process: The Role of Information Analysis in Reaching Safeguards Conclusions" (Mathews et al. 2008), several examples of nonproliferation models using analytical software were developed that may assist the IAEA with collecting, visualizing, analyzing, and reporting information in support of the State Evaluation Process. This paper focuses on one of the examples - a set of models developed in the Proactive Scenario Production, Evidence Collection, and Testing (ProSPECT) software that evaluates the status and nature of a state's nuclear activities. The models use three distinct subject areas to perform this assessment: the presence of nuclear activities, the consistency of those nuclear activities with national nuclear energy goals, and the geopolitical context in which those nuclear activities are taking place.

As a proof-of-concept for the models, a crude case study was performed (a summary of the proof-ofconcept is in Appendix D). The study, which attempted to evaluate the nuclear activities taking place in Syria prior to September 2007, yielded illustrative, yet inconclusive, results. Due to the inconclusive nature of the case study results, changes that may improve the model's efficiency and accuracy are proposed. 



\section{Acronyms and Abbreviations}

B - Belief

$\mathrm{B}_{\mathrm{c}}$ - Complement of Belief

IAEA - International Atomic Energy Agency

ProSPECT - Proactive Scenario Production, Evidence Collection, and Testing

SLA - State Level Approach

Pl - Plausibility

$\mathrm{Pl}_{\mathrm{c}}-$ Complement of plausibility

PNNL - Pacific Northwest National Laboratory

POC - Proof of Concept

WMD - Weapons of Mass Destruction 



\section{Contents}

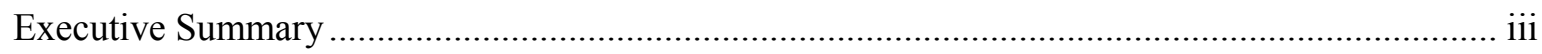

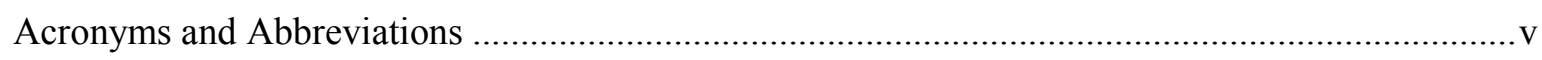

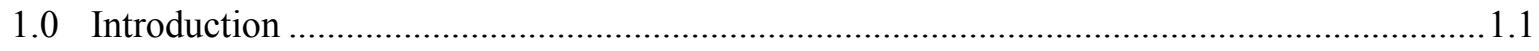

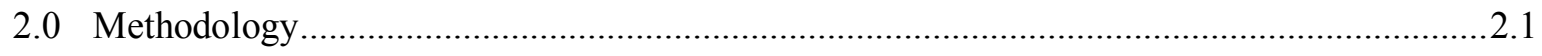

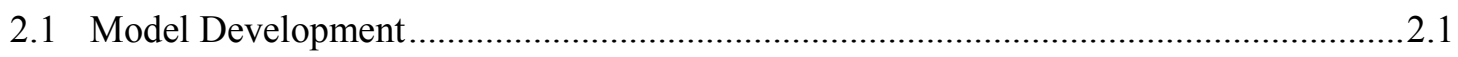

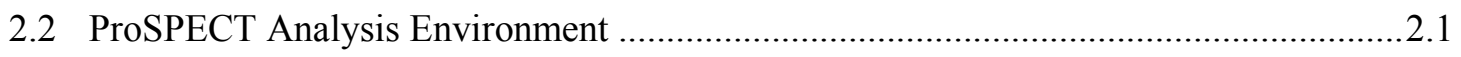

2.2.1 Defining a Conceptual Framework in ProSPECT: Hypotheses and Sub-

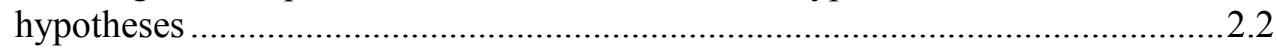

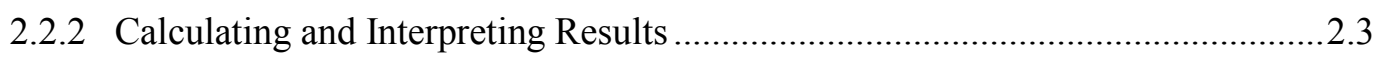

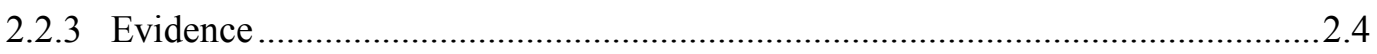

2.3 Developing a Model to Evaluate the Status and Nature of a State's Nuclear Activities.2.5

2.3.1 Presence of Nuclear Activities ..........................................................................2.6

2.3.2 The Consistency of Nuclear Activities with Declared Nuclear Energy Goals .....2.9

2.3.3 Geopolitical Context in Which Nuclear Activities are Taking Place..................2.12

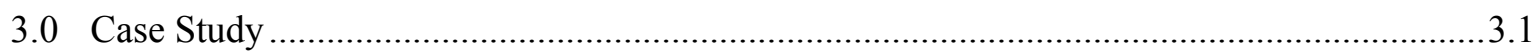

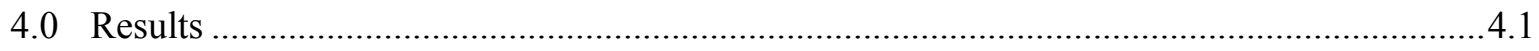

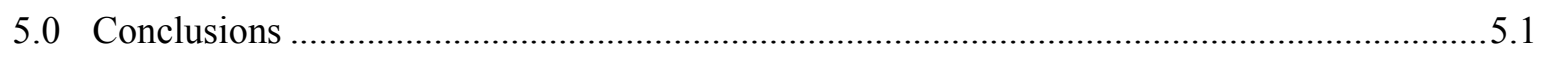



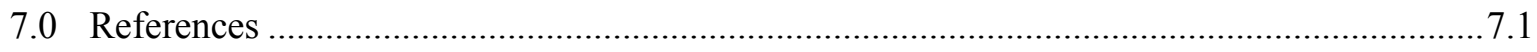

Appendix A Presence of Nuclear Activities ........................................................................... 1

Appendix B Consistency of Nuclear Activities ....................................................................... B. 1

Appendix C Geopolitical Context of Nuclear Activities ........................................................... 1

Appendix D Proof of Concept (POC) - Summary ................................................................... D. 1

Appendix E Sources Used in Syria Model........................................................................... E. 1 


\section{Figures}

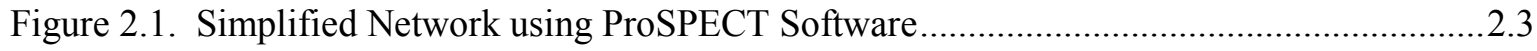

Figure 2.2. Example Confidence Levels for Sources of Evidence.................................................2.5

Figure 2.3 Example Decision-Tree Format for Model Analysis...................................................2.6

Figure 2.4. Presence of Nuclear Activities Network................................................................2.8

Figure 2.5. The Consistency of a State's Nuclear Activities ....................................................2. 11

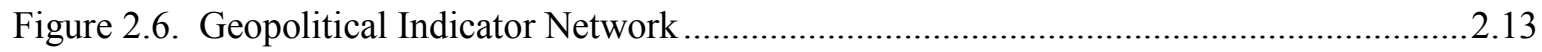

\section{Tables}

Table 4.1. ProSPECT Model Results.................................................................................... 4.1 


\subsection{Introduction}

The historical conversion of peaceful nuclear activities (e.g. nuclear power plants) to serve nuclear weapons programs has resulted in the need for an improved capability for determining the status and nature of a state's nuclear activities. Although every case of nuclear proliferation is unique, the need to determine the nature of nuclear activities is universal. Under the IAEA's State-Level Approach (SLA) for nuclear safeguards, more effort is being placed on evaluating not only a state's declared nuclear activities, but also the context in which those, and other, activities are taking place.

Stephen Meyer noted in The Dynamics of Nuclear Proliferation (Meyer 1984), "Nuclear proliferation [can] no longer be viewed as the well-defined black-to-white jump to nuclear weapons status. Instead, it [has] to be seen as a developmental process reflecting the growth of latent capacities around the globe." With the expected increase in nuclear energy activities around the world in the next 20-30 years, more states than ever before will be engaging in nuclear activities. If the worldwide growth of nuclear energy occurs as its proponents currently envision, the ambiguity highlighted by Meyer will increase. The threat of new states developing nuclear weapons programs will also increase. As such, it is a critical time to be able to evaluate a state's nuclear activities more holistically, taking into consideration the activities themselves, how they relate to a state's energy needs and goals, and the geopolitical contexts in which they are taking place.

As a means to address the growing proliferation concerns associated with the expansion of global nuclear energy, and in support of the IAEA's SLA for international safeguards, a set of three models was developed in the ProSPECT software to evaluate the status and nature of a state's nuclear activities, each focusing on a single subject area: The first model attempts to determine whether or not nuclear activities are taking place within the state. The model second analyzes the declared and perceived nuclear activities against the state's national energy needs and goals, to check for consistency. Finally, the third model addresses the geopolitical context in which nuclear activities are taking place within a state, which has the potential to alter how nuclear activities are interpreted. 



\subsection{Methodology}

The three models developed for the assessment of the status and nature of a state's nuclear energy program were developed and evaluated using the ProSPECT software, being developed at the Pacific Northwest National Laboratory (PNNL). ProSPECT provides a graphic-based analysis environment in which models can be constructed and populated with supporting evidence.

\subsection{Model Development}

Model-building begins with defining the analytical question to be answered by the model, and formulating hypotheses that address the question. Each model consists of hypotheses and subhypotheses, arranged in a logical pattern to answer the analytical question. A critical factor in developing models is defining the hypotheses and sub-hypotheses in such a way that they can be answered objectively through the insertion of evidence to the model.

It may sometimes be practical to evaluate the analyst's objectives using a single model with one, two, or more competing hypotheses. The example presented here incorporates three separate models, which should be analyzed together for a clear picture not only of what nuclear activities are taking place within a state, but also how those activities relate to known information about the state-specifically, interaction of the activities with national needs and goals, and the state's geopolitical context.

\subsection{ProSPECT Analysis Environment}

The ProSPECT analytical environment allows for model development, evidence collection, evidence marshalling, and the application of evidence to the model.

Unlike similar modeling tools used for scenario analysis, like Analysis of Competing Hypotheses or Bayesian Networks, the Dempster-Shafer approach used in ProSPECT enables the user to capture complex networks in which hypotheses and evidence are linked with a semi-quantitative scheme, rather than requiring the definition of exact probabilistic relationships.

Dempster-Shafer is a generalization of Bayesian probability theory that relies on three functions: basic probability assignment, belief, and plausibility (Sanfillipo et al. 2007). The probability of an outcome is bounded on either side by the analyst's belief and its plausibility. The model combines evidence, calculating overall probability $(m(A))$ by simply taking the average of the probability assignments associated with specific beliefs $(m)$ and weights $(w)$ reflecting the reliability of pieces of evidence: Rather than requiring the specification of complete joint probabilities for hypotheses, the user assigns strength and confidence based on a Likert psychometric scaling measure. This allows an intuitive strength assignment based on a 7-point scale, in which the magnitudes of strength and confidence are seen graphically rather than quantitatively assigned. The averages are calculated by fitting the analyst's graphical assignment of strength and confidence to a number scale (Sanfillipo et al. 2007).

$$
m(A)=\frac{1}{n} \sum_{i=1}^{n} w_{i} m_{i}(A)
$$


By combining a graphical interface with intuitive strength- and confidence-assignment capabilities, all built on a framework of Dempster-Shafer probability theory, the user can easily create networks that minimize biases and reflect a union of evidence and analytic scrutiny.

ProSPECT allows analysts to semi-quantitatively define the extent to which a sub-hypothesis supports or refutes its parent hypothesis (defined as strength). The user assigns each sub-hypothesis a strength level, either indicating support or refutation of its parent. When evidence is added to the network, a similar strength indicator is given, which represents the impact of the evidence on its associated hypothesis. Strength levels are easily modified, and automatically recalculate belief scores for the model.

The ProSPECT environment allows the user to document evidence and formalize his or her thought process, clarifying thinking and providing gauges of proliferation potential, instead of rigid binary results, which could be done on a document-by-document basis, or for larger datasets. ProSPECT provides an intuitive interface for meeting these goals, supporting evidence gathering, relationship identification, and model building. .

The evidentiary approach underlying the model supports the examination and comparison of parallel scenarios simultaneously, without requiring the user to specify joint probability distributions. The model employs Dempster-Schafer theory as the mechanism for hierarchical ordering of uncertainties based on hypotheses, sub-hypotheses, and documented evidence. This method is especially applicable for international security and nuclear proliferation assessments, due to its ability to work with vague or uncertain evidence.

\subsubsection{Defining a Conceptual Framework in ProSPECT: Hypotheses and Sub- hypotheses}

The ProSPECT Analysis Space is the analytical environment in which the analyst constructs and evaluates a model. The conceptual framework of ProSPECT models consist of hypotheses and subhypotheses which support the evaluation of the analytical question. The relationship between hypotheses and sub-hypotheses is called strength. If the sub-hypothesis supports its parent hypothesis, strength is positive. If the sub-hypothesis refutes its parent hypothesis, the strength is negative. Strength is denoted in the strength box, which lies along the lines connecting sub-hypotheses with hypotheses, and evidence with hypotheses or sub-hypotheses. Strength boxes have vertical lines, which indicate support of the parent hypothesis (in green, to the right of center) or refutation of the parent hypothesis (in red, to the left of center).

Evidence is information collected by the analyst and applied to the model to either support or refute the hypotheses and sub-hypotheses. As with the definition of relationships between sub-hypotheses and their parents, the relationships must also be defined between evidence and the hypotheses that it supports or refutes in the strength box, located on the arrow connecting the evidence and its parent hypothesis. The truthfulness of the evidence is evaluated by the analyst with a confidence rating. The confidence rating is attached to the upper left corner of the evidence, and can be positive, negative, and/or uncertain. The green horizontal bars in the confidence histogram indicate how much the analyst believes the evidence is true; red indicates how much the analyst believes the evidence is false. A gray bar represents uncertainty. Uncertainty is the difference between analyst belief in the truth or falseness of the evidence and full belief. 


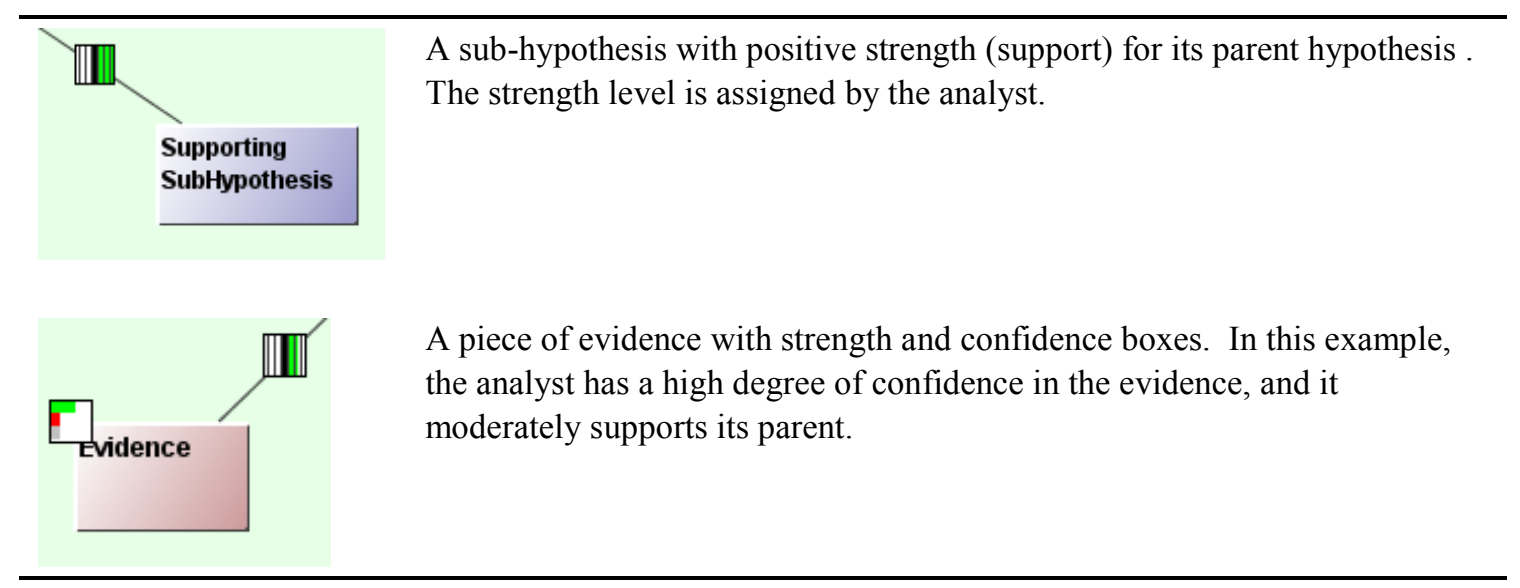

Figure 2.1 depicts a simplified model with a main hypothesis, supporting and refuting sub-hypothesis, and evidence. The strength and confidence ratings are assigned by the analyst.

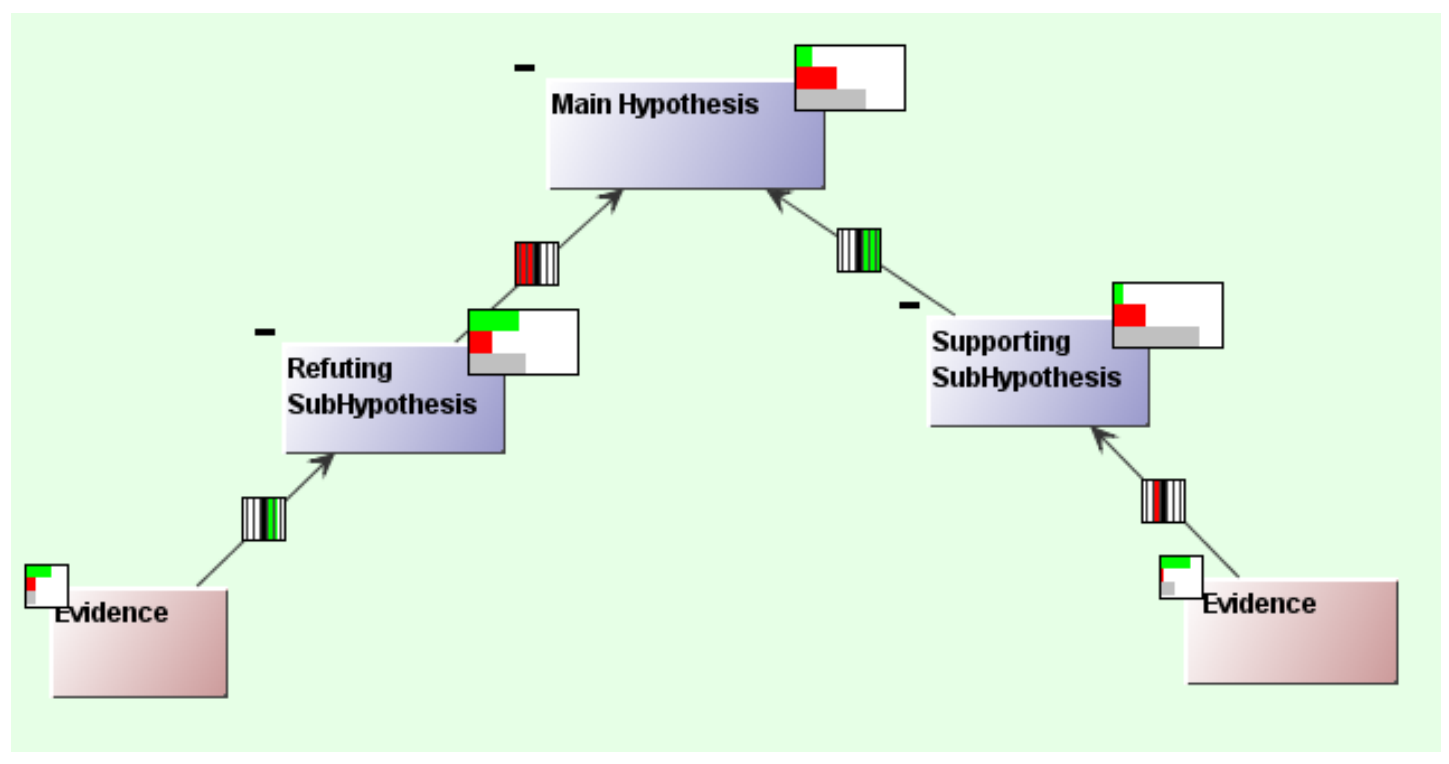

Figure 2.1. Simplified Network using ProSPECT Software

\subsubsection{Calculating and Interpreting Results}

Using Dempster-Shafer mathematics, the strength and confidence ratings are factored up throughout the entire model. Results are displayed on each hypothesis and sub-hypothesis in boxes attached at the top right corner. There are five distinct results measures calculated by ProSPECT: Belief, disbelief, uncertainty, plausibility, and implausibility. Each result is defined as follows:

- Belief (B) - Degree of support of the hypothesis, as a percentage of complete support.

- Disbelief $\left(\mathrm{B}_{\mathrm{c}}\right)$ - The complement of belief, as a percentage of complete support. 
- Uncertainty (U) - The difference between belief, disbelief, and complete support.

- Plausibility $(\mathrm{Pl})$ - The sum of belief and uncertainty. Represents the maximum possible degree of belief in the hypothesis.

- Implausibility $\left(\mathrm{Pl}_{\mathrm{c}}\right)$ - The sum of disbelief and uncertainty. Represents the maximum possible degree of disbelief in the hypothesis.

Results are displayed in four ways in the ProSPECT Analysis Space:

1. As a histogram. Green represents expected belief in the hypothesis. Red represents disbelief of the hypothesis, and gray represents uncertainty.



2. As a percentage. Belief is indicated in green, on the top bar, and disbelief is indicated in red on the bottom bar. The belief percentage scores are the numeric values that define the histogram results.

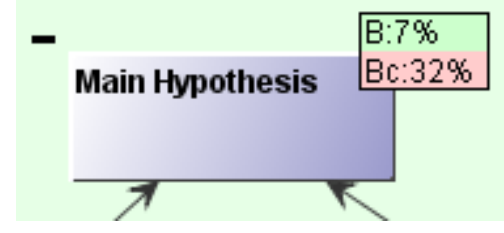

3. As a plausibility score. Plausibility is displayed in the green bar on the top, and un-plausibility is displayed in the red bar on the bottom of the results box.

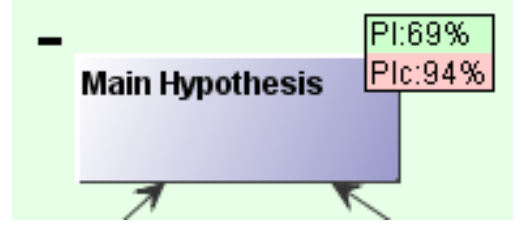

4. As a range of belief to plausibility, and disbelief to the implausibility. The belief-plausibility range represents the entire range of support that the model could yield, and is displayed in the green bar on the top of the results. The disbelief-implausibility range indicates all possible refutation that the model could yield, and is displayed in red on the bottom bar of results.

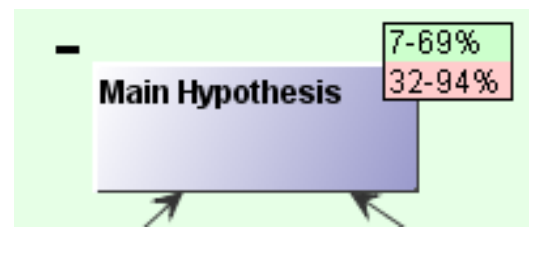

\subsubsection{Evidence}

Evidence is incorporated into the ProSPECT model to support or refute hypotheses and subhypotheses. This evidence can take many forms, such as news articles, photos, satellite imagery, common 
knowledge, or many other forms (including movies or audio information). When adding evidence to a ProSPECT mode, the analyst assigns a strength rating to indicate how much the evidence supports or refutes its corresponding hypothesis, as well as a confidence rating to indicate how true or false the analyst believes the evidence to be. Confidence is a unique score for evidence, indicating the degree to which the analyst believes the evidence if true or false. While individual sources will be evaluated separately, generalizations regarding how much confidence the analyst can have in a piece of evidence are provided below in Figure 2.2. Examples of evidence that generally carry high degrees of confidence include official government reports or intelligence, information from international organizations, peerreviewed journals, or encyclopedias. Sources that would merit less confidence include blogs, articles from non-peer-reviewed publications, or media reports.

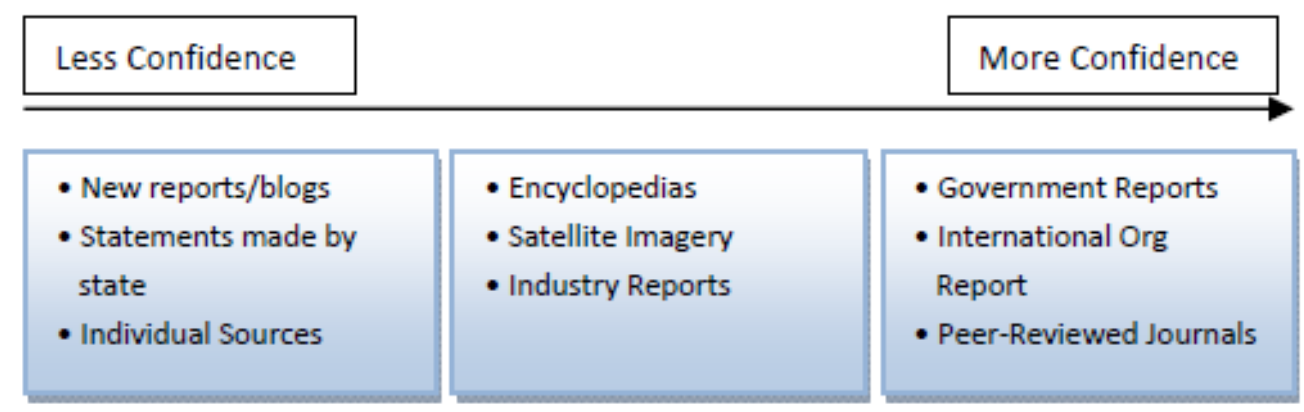

Figure 2.2. Example Confidence Levels for Sources of Evidence

\subsection{Developing a Model to Evaluate the Status and Nature of a State's Nuclear Activities}

Three models were developed to address the analytical question - "Are the nuclear activities of a state cause for proliferation concern?" Each model addresses a single subject to support the evaluation of the analytical question. The three models address:

1. The presence of nuclear activities within the state

2. The consistency of nuclear activities with the state's declared nuclear energy goals

3. The geopolitical situation surrounding nuclear activities

The models were developed separately, and do not have a formal method for integrating results. The separation of the models was used to encourage independent analysis of each model, and interpretation of each model's results in context of the others. Because each model has the potential to influence the others in this way, it was decided to keep the models as separate entities rather than rolling them into a larger model. Keeping these models separate, yet evaluating them together, offers the analyst more freedom in interpreting the results from each model (if it is determined in the future that the models should be combined into a single assessment, the potential to do so exists). For example, if the models evaluating the presence and consistency of a state's nuclear activities indicate that a state is pursuing nuclear activities inconsistent with national energy needs and goals, that may be sufficient to determine that there is need for proliferation concern, without having to analyze the state's geopolitical concerns. Likewise, if the model evaluating the presence of nuclear activities within a state indicates that there are no nuclear activities taking place, the consistency model would be irrelevant. However, the model for analysis of the 
geopolitical context may still be indicative of potential proliferation concern - especially if the state is considering the development of nuclear activities.

While not proscribed, the analysis of the three models could potentially be analyzed in a decision-tree format. An example of a decision-tree format for analysis of the three models is presented in Figure 2.3.

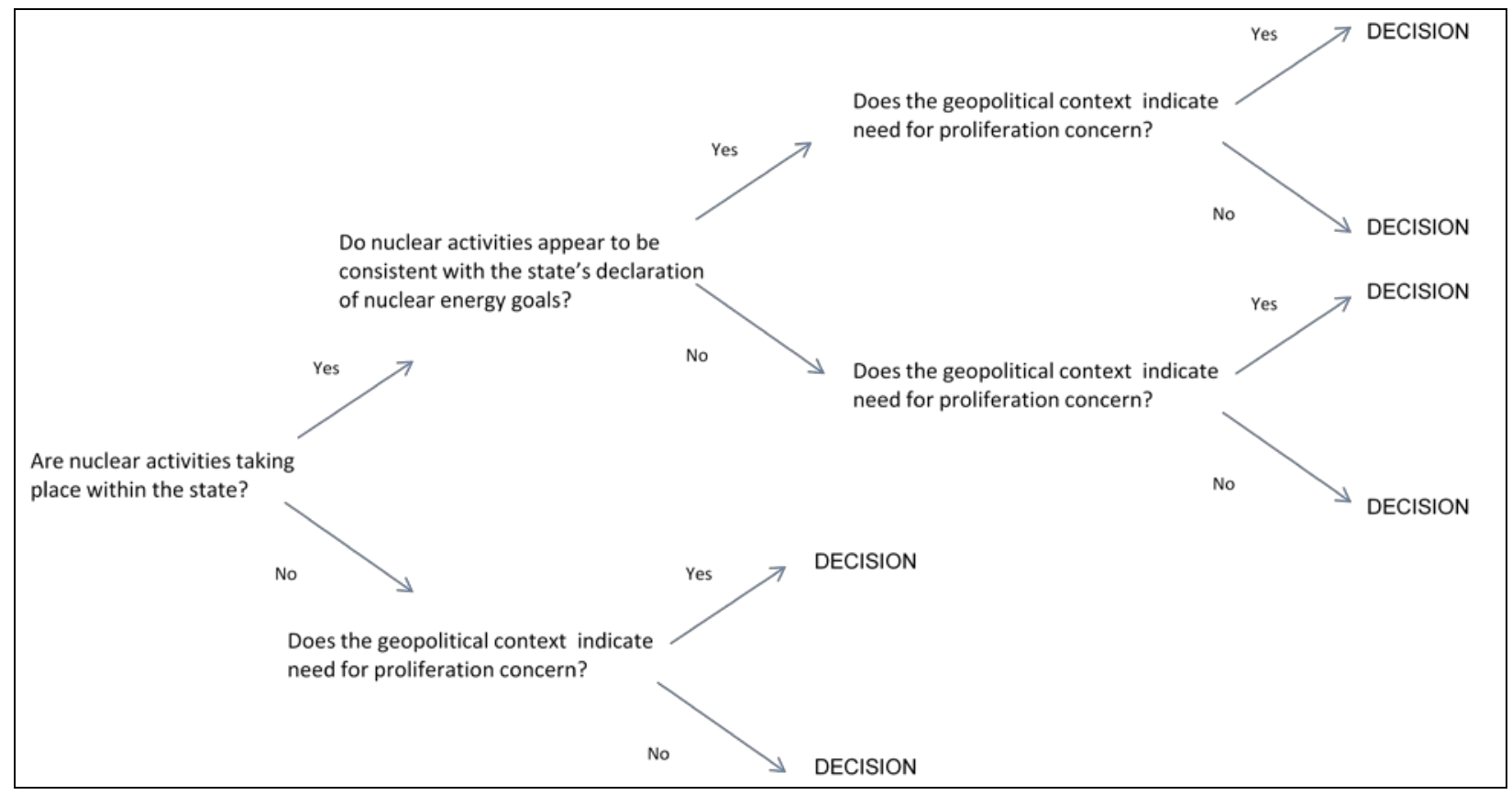

Figure 2.3 Example Decision-Tree Format for Model Analysis

\subsubsection{Presence of Nuclear Activities}

The first model asks the question, "Are nuclear activities taking place in the state?" This model serves as the foundation and justification for the other two models in the series. To determine whether nuclear activities are of proliferation concern, the analyst must first determine that nuclear activities are indeed taking place.

To answer this question, the analysis focuses on four major subject areas:

1. Government structure and statements: The structure of a government, as well as the official statements coming from that government, can provide indication of nuclear energy activities within a country. For example, the presence of an atomic energy administrative body indicates that nuclear activities may be taking place in the state. Furthermore, statements from elected officials regarding nuclear energy research or plans can indicate nuclear activities, or plans for nuclear activities.

2. Professional and academic activities: Professional and academic activities can provide indication of nuclear activities from the public sector, as opposed to official statements from the government. These public sector indicators can include academic research; professional activities and organizations related to nuclear energy or research; publications; university programs in nuclear engineering, physics, or radiochemistry; research reactors; or other nuclear-related laboratory facilities. 
3. International cooperation and trade: State participation in international cooperation and trade related to nuclear energy or nuclear research can serve as an indicator of nuclear activities taking place within the state. These cooperation and trade activities include ratification of nuclear trade agreements; membership in nuclear cooperation organizations (such as World Association of Nuclear Operators or Nuclear Suppliers Group); and participation in IAEA Technical Cooperation projects or other bilateral or multilateral nuclear cooperation projects.

4. Nuclear, or nuclear-related, imports and exports: Records of a state's imports and exports related to nuclear energy or technology may indicate the presence of nuclear, or nuclear-related, activities within a country. These imports and exports can include nuclear-trigger-list materials or technology; or dual-use items.

These variables and their relationships to each other can be seen in Figure 2.4. 


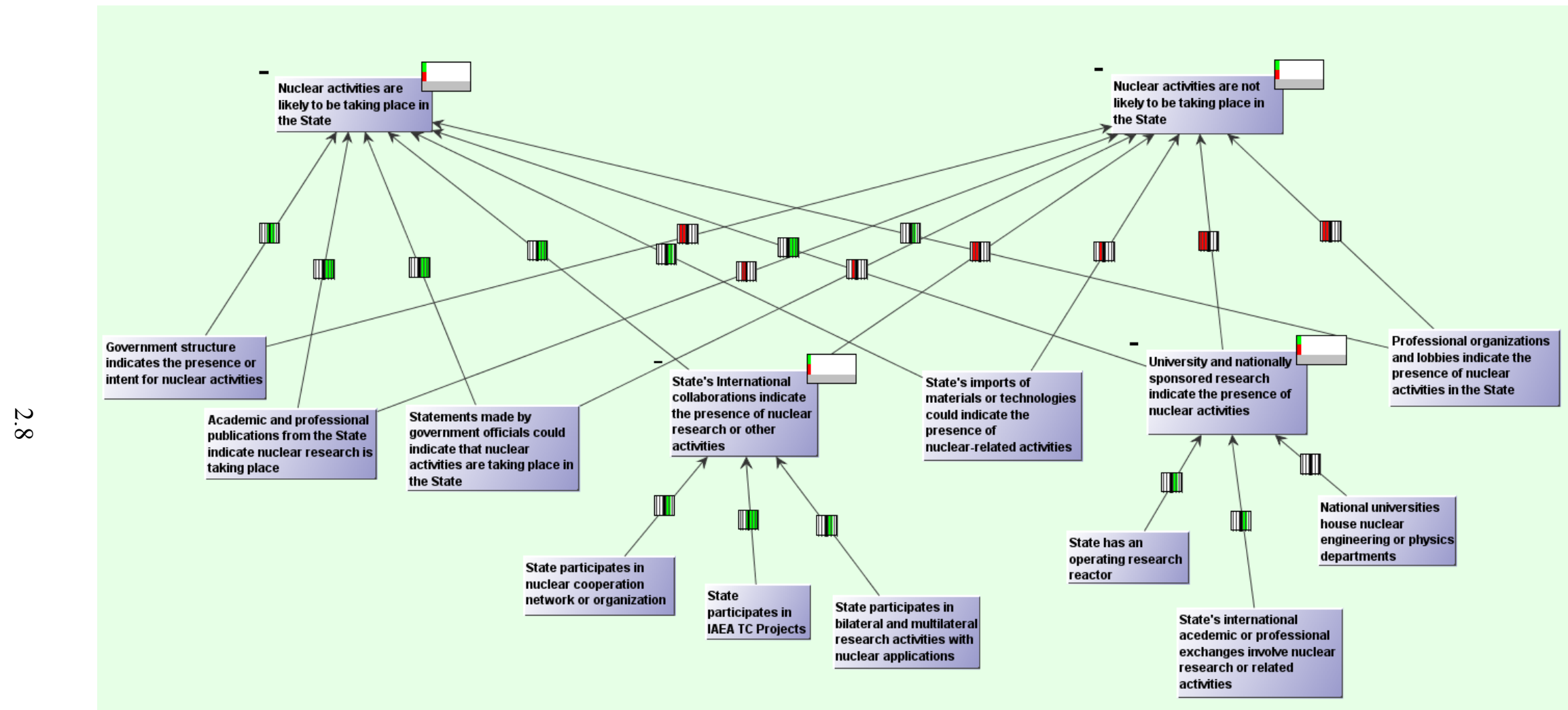

Figure 2.4. Presence of Nuclear Activities Network 
The results of this model should point to either the existence or absence of a nuclear program. If the evidence incorporated into the model indicates that nuclear activities are taking place in a state, the consistency and geopolitical context models should be evaluated. For states with no clear indication of nuclear activities, it may still be useful to evaluate the geopolitical model. This is especially important because the model can only utilize known information-that is, even if a country does not have declared or obvious nuclear activities, it may be concealing a nuclear program.

\subsubsection{The Consistency of Nuclear Activities with Declared Nuclear Energy Goals}

The second model evaluates the consistency of nuclear activities with the state's declared national energy needs and goals. The analysis of nuclear activity consistency is unique to this model framework. By attempting to identify activities and characteristics of nuclear programs that are inconsistent with declared goals, analysts can construct more informed evaluations of nuclear activities. If any nuclear activities have features that are incompatible with their stated purpose, the consistency of those activities with national goals becomes questionable, and may be determined to be of proliferation concern.

The rationale for emphasizing consistency is as follows: If a country is pursuing a complete fuel cycle in an effort to become energy independent, has the economic means and justification to do so, and is striving for those goals within an appropriate context of R\&D in renewable and other energy sources, its context indicates legitimacy. However, nuclear energy pursuits that do not appear to be consistent with the country's declared nuclear energy goals may warrant proliferation concern. For example, a state that possesses the technology and material needed to fabricate nuclear weapons, but does not explain their relevance in terms of nuclear energy goals, would be the subject of greater proliferation concern.

The analysis of the consistency of a state's nuclear energy activities with its declared goals focuses on five major subject areas:

1. Location: The location of nuclear-related facilities may be indicative of the application of the activities taking place at those facilities. For example, if a state claims to be developing a nuclear power plant to provide electricity to a population center, but the power reactor is sited a great distance from electricity transmission lines, this could demonstrate an inconsistency between nuclear energy goals and activities. Analysis of the location of a nuclear facility considers the location of a facility compared to other energy, research, and development facilities; infrastructure the facility; and proximity to population centers.

2. Consistency of Perceived Activities: While not all activities taking place at a nuclear center may be obvious, the consistency of perceived activities with the declared purpose of a facility may be indicative.

3. Imported Material/Technology: Nuclear and dual-use materials and technologies have limited industrial and nuclear applications. As such, an analysis may be performed to determine whether or not the nuclear and dual-use materials and technologies appear consistent with the state's declared uses of those items.

4. Efficiency and Cost Effectiveness of known Facilities/Technologies: The efficiency and costeffectiveness of a state's nuclear activities can provide insight to the consistency of those activities with the state's declared nuclear activities and goals. For example, large investments in technologies 
which are inefficient for their declared uses, but efficient for weapons-related uses, could lead to inconsistency in the state's nuclear activities.

5. Security Assessment of Facilities and Locations: The apparent security measures surrounding declared nuclear facilities may indicate whether the activities taking place at those facilities are consistent with declared activities and goals.

These variables, and their relationships to one another, are shown in Figure 2.5.

If nuclear activities are consistent with a state's goals for energy, research, and development purposes, it may still be subject to proliferation concern. If some nuclear activities are determined to be inconsistent with a state's nuclear energy goal, those activities should be carefully examined to determine if they could result in the state acquiring nuclear material or technology that could be used in the development of a nuclear weapons program. 


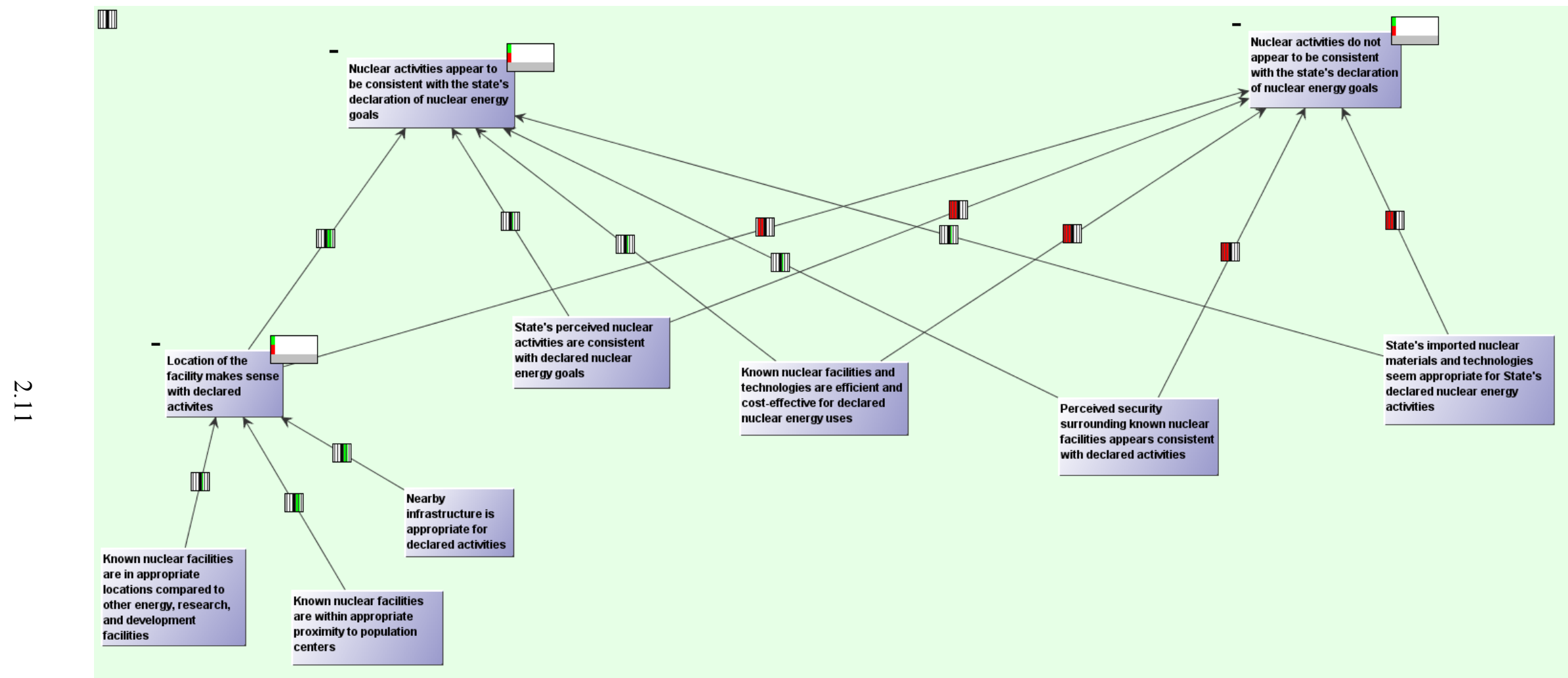

Figure 2.5. The Consistency of a State's Nuclear Activities 
The questions posed for analysis in the consistency model are the most difficult to evaluate because they require much more analyst interpretation of information. While the other models focus greatly on information collection and organization using massive amounts of data, this model utilizes more specific analysis. The evaluation of this model requires that the analyst to combine several pieces of detailed analysis and evaluation into a single model.

\subsubsection{Geopolitical Context in Which Nuclear Activities are Taking Place}

The third model focuses on analyzing the geopolitical context in which nuclear activities are taking place. The model draws heavily from social science literature that seeks to explain why states explore, pursue, or acquire nuclear weapons. The model does not rely on any specific nuclear-related information, except for analysis of neighboring countries' nuclear activities. Though this portion of the model is unable to draw conclusions regarding a state's nuclear programs, the importance of these geopolitical factors in determining nuclear proliferation has been discussed by a plethora of international relations theorists and scholars. The strength of the third model lies in its ability to create a conceptual framework for examining the results of the models describing the presence and consistency of a state's nuclear activities.

The model evaluating the geopolitical context in which a state's nuclear activities are taking place centers around four major subject areas:

1. Regional/International Security: By understanding the regional and international security environment that surrounds a state analysts can better determine the forces acting upon a state that could motive or deter it from developing a nuclear weapons program. Regional and international security threats can be indicated by a state's neighbors or rivals with nuclear weapons or nuclear weapons programs; or regional or international tensions.

2. Pursuit of Other Weapons of Mass Destruction (WMD): A state's previous endeavors related to chemical, biological, radiological, or nuclear WMD affect the state has engaged in the pursuit or acquisition of a non-nuclear WMD, it may be more likely to have an interest in securing a nuclear weapon. This sub-hypothesis reflects the assumption that if a leader believes mass civilian casualties are acceptable if achieved through one type of weapon, other types of WMDs are acceptable as well.

3. Deterrent: Depending on their international integration, different states will suffer different consequences if they were to develop a nuclear weapons program. For example, the threat of economic sanctions might dissuade the leader of a state from pursuing nuclear weapons. Factors that influence the deterrent effect include political integration; economic integration; and expected ally response to the state's pursuit of a nuclear weapons program.

4. National Nonproliferation Norms: A state's commitment to nonproliferation norms influences how nuclear activities in that state are perceived. Indicators of commitment to nonproliferation norms include participation in nonproliferation and arms control initiatives; the robustness and implementation of national export control policies; and public statements or press releases from officials that denounce the need or desire for nuclear weapons.

These indicators, and their relationships to one another, are presented in Figure 2.6. 




Figure 2.6. Geopolitical Indicator Network 

The factors influencing the geopolitical context of a state's nuclear activities serve as a summary of a large body of social science research attempting to determine why state's develop nuclear weapons.

However, the forecasting of which states will be the next to develop nuclear weapons is highly controversial, and often incorrect. As such, this model seeks to utilize the characteristics of potential proliferant states not as indicators that the state will develop nuclear weapons, but as potential "red flags" that, combined with analysis of the other models presented here, can help analysts determine if the state's nuclear activities are cause for proliferation concern. 



\subsection{Case Study}

After the three models were constructed, a case study was evaluated to help validate and verify the models.

In September 2007, an Israeli airstrike illuminated an undeclared nuclear reactor that had been under construction in Syria. The reactor resembled a North Korean reactor used in that country's nuclear weapons program. Because nuclear weapons-related activities were not widely suspected before the airstrike, Syria was chosen as a case study to test the ProSPECT models. The case study utilized only

pre-September 2007, open-source information to determine whether Syria's nuclear activities could have been identified as a proliferation concern. For a list of sources used in the case study, see Appendix E. 



\subsection{Results}

An explanation of the results of the test case is presented below. A full display of results is shown in Table 4.1. The models, including the case study evidence, are presented in Appendices A-C.

1. Presence of Nuclear Activities: The model with the hypothesis, "Nuclear activities are likely to be taking place within the state," resulted in $48 \%$ belief, with $100 \%$ plausibility. The null hypothesis, "Nuclear activities are not likely to be taking place in the state," resulted in $0 \%$ belief, with $67 \%$ plausibility. Nuclear activities were confirmed, inter alia, by the existence of Syria's Atomic Energy Commission, statements made by government officials, a university research reactor, imports of nuclear-relevant material, and participation in IAEA technical cooperation projects. The uncertainty in the model appears to be driven by the ambiguity surrounding Syria's participation in nuclear cooperation networks or organizations.

2. Consistency of Nuclear Program: The model with the hypothesis, "Nuclear activities appear to be consistent with state's declaration of nuclear energy goals," resulted in $8 \%$ belief and $98 \%$ plausibility. The null hypothesis, "Nuclear activities do not appear to be consistent with the state's declaration of nuclear energy goals," resulted in 3\% belief and 79\% plausibility. Though the belief values are relatively small, the results indicate that it is slightly more likely that nuclear activities appear to be consistent with the Syrian declaration of nuclear energy goals.

3. Geopolitical Environment: The model with the hypothesis, "Geopolitical situation surrounding nuclear activities does not indicate need for proliferation concern," resulted in 1\% belief and 86\% plausibility. The null hypothesis, "Geopolitical situation surrounding nuclear activities could indicate need for proliferation concern," resulted in 15\% belief and 99\% plausibility. The results of the model indicate that there is a slightly higher probability that the geopolitical situation could lead to an increased nuclear proliferation concern, particularly due to regional and international tension, Syria's previous pursuit of non-nuclear WMDs in the form of chemical weapons, and opaque participation in arms control collaborations. Furthermore, leaders have never gone on record denouncing nuclear weapons (except related to Israeli weapons), and potential regional balance of power issues could persuade the state to develop weapons-producing capability. The geopolitical model yields higher uncertainty values than the other models, primarily due to uncertainty regarding the robustness of Syrian safeguards and export control policies.

Table 4.1. ProSPECT Model Results

\begin{tabular}{lcccc}
\hline \multicolumn{1}{c}{ Hypothesis } & Belief (\%) & $\begin{array}{c}\text { Complement of } \\
\text { Belief (\%) }\end{array}$ & Plausibility ${ }^{1}$ (\%) & $\begin{array}{c}\text { Complement of } \\
\text { Plausibility }{ }^{2}(\%)\end{array}$ \\
\hline $\begin{array}{l}\text { Nuclear activities are likely to be } \\
\text { taking place in the state }\end{array}$ & 48 & 0 & 100 & 52 \\
$\begin{array}{l}\text { Nuclear activities are not likely } \\
\text { to be taking place in the state }\end{array}$ & 0 & 33 & 67 & 100 \\
\hline
\end{tabular}

\footnotetext{
${ }^{1}$ Plausibility $=$ Belief + Uncertainty

${ }^{2}$ Complement of Plausibility $=$ Complement of Belief + Uncertainty
} 


\begin{tabular}{lllll}
\hline $\begin{array}{l}\text { Nuclear activities appear to be } \\
\text { consistent with state's declaration } \\
\text { of nuclear energy goals }\end{array}$ & 8 & 2 & 98 & 92 \\
$\begin{array}{l}\text { Geopolitical situation } \\
\begin{array}{l}\text { surrounding nuclear activities } \\
\text { does not indicate need for } \\
\text { proliferation concern }\end{array}\end{array}$ & 1 & 14 & 86 & 96 \\
$\begin{array}{l}\text { Geopolitical situation } \\
\text { surrounding nuclear activities } \\
\begin{array}{l}\text { could indicate need for } \\
\text { proliferation concern }\end{array}\end{array}$ & 15 & 2 & 99 & 86 \\
\hline
\end{tabular}




\subsection{Conclusions}

Preliminary results were illustrative, but did not conclusively indicate the need for proliferation concern regarding Syria's nuclear activities. Taking the three models as a whole, the results are inconclusive, and do not necessarily reflect a pronounced need for increased proliferation concern. Presence of nuclear activities is confirmed with a high degree of confidence, but geopolitical environment and consistency nuclear activities are dominated by uncertainty. Preliminary results indicate, though with high uncertainty, that nuclear activities appear to be consistent with declared goals, and that the geopolitical situation could indicate a need for proliferation concern. These indicators, however, are quite subtle. Inconclusive results may be due to the significant uncertainty in the model. With the advantage of hindsight, it may be possible to conclude that the inconclusive results were driven by the inability to detect or evaluate Syria's clandestine nuclear activities. However, the uncertainty in the model, without strong conclusions in favor of proliferation concern, could also have led analysts to disregard potential the potential Syrian proliferation threat.

Uncertainty dominates the results for the case study, resulting from both the analyst's confidence in the evidence and the strength assigned to the sub-hypotheses. However, uncertainty should be expected when attempting to determine the presence of, and evaluate, clandestine military activities. This is a natural result for matters of national security. The less transparent a state is, in terms of public statements, media access, international partnership, and research activities, the less confidence there can be in the evidence related to government statements or other official media.

Even inconclusive results can be meaningful, and analysis should focus on which hypothesis has the strongest support, and why such high levels of uncertainty exist. The analyst may ask: Why is it so unclear as to whether the country's nuclear activities support its declared energy needs and goals? High uncertainty itself may be indicative of the need for proliferation concern. As Jim Walsh stated in his paper, written for the Weapons of Mass Destruction Commission, "Unlike most houseplants, nuclear programs grow best in the dark" (Walsh 2005). 



\subsection{Recommendations}

For future research, additional relevant sub-hypotheses may be incorporated into the models. Though they are not included in this analysis, other factors may potentially augment the model evaluating the consistency of a state's nuclear program with the states declared nuclear energy needs and goals. Those factors include:

1. Historical Development of Nuclear Program: Determining the historical development and purpose of a nuclear program may shed light on the consistency of current nuclear activities. For example, if a nuclear program began for military purposes, complete with missile and weapons research, and was later converted to peaceful use, some concern might remain as to technology, fissile material availability, and weapons development.

2. Electricity Generation and Use: Analyzing the state's electricity supply and demand could determine if nuclear activities actually support nuclear energy needs. If nuclear energy is declared as providing a segment of the electricity required by the state, the entire power-generation portfolio should be examined, with the aim of determining whether nuclear facility is actually meeting the declared supply and demand.

3. Economic Coherence Analysis: Analysis of the state's industrial inputs and outputs may be able to determine if they are consistent with non-nuclear weapons state.

4. Academic Programs, Publications, etc.: The presence of academic programs or publications associated with nuclear technology beyond the scope of declared energy technology or goals may indicate inconsistency of nuclear activities.

Furthermore, the "consistency" model repeatedly refers to the analysis of nuclear activities compared to national energy goals related to nuclear activities. However, no analysis is done to determine if those nuclear energy needs and goals are appropriate for a state. As such, national nuclear energy goals should also be evaluated to determine if they are appropriate and realistic for the state. States with reasonable and consistent goals and activities should still be assessed. However, more attention should be paid to states in which activities appear inconsistent with nuclear energy goals.

Additional research completed since the development and evaluation of the models suggest that other factors could also be useful for the "geopolitical context" model. These factors include:

1. Domestic Politics and Leadership: Social science literature suggests that certain political systems and leadership types enable nuclear weapons proliferation more than others.

2. National Identity and Prestige: National identity and status/prestige may influence a state's willingness or motivation to develop a nuclear weapons program. For example, a state that feels disenfranchised or alienated from the rich countries might feel compelled to flex its military muscle and gain prestige on the national stage.

3. Fuel Supply Guarantees or Other Trade Relationships: A guarantee of fuel supply through supply guarantees, or other trade mechanisms, could induce a state to be less inclined to develop sensitive fuel-cycle technologies. 
Once finalized models are in place, it is recommended that further test cases be conducted to determine whether the model is able to differentiate between states that are developing clandestine nuclear weapons programs (this would include historical analysis such as the Syria case study), and other types of states - such as those with highly developed nuclear capabilities but that are not expected to develop nuclear weapons, or states with moderate nuclear capabilities with tense international security conditions. Potential case studies could also include states that have recently been identified by social science literature as potential proliferant states in the next 10-20 years, such South Korea, Japan, Turkey, or Saudi Arabia, (identified as states likely to develop nuclear weapons by Lavoy and Walker 2006). 


\subsection{References}

1. Mathews C, R Hooper, G, Anzelon, J Essner, J Tape, R and Wallace. 2008. The International Atomic Energy Agency State Evaluation Process: The Role of Information Analysis in Reaching Safeguards Conclusions. PNNL-17838, Pacific Northwest National Laboratory, Richland, Washington.

2. Meyer S. 1984. The Dynamics of Nuclear Proliferation. University of Chicago Press, Chicago, Illinois.

3. Sanfillipo A, B Baddely, C Posse, and P Whitney. 2007. "A Layered Dempster-Shafer Approach to Scenario Construction and Analysis." In: IEEE International Conference on Intelligence and Security Informatics, May 23-25, New Brunswick, New Jersey.

4. Walsh J. 2005. Lessons from Success: the NPT and the Future of Non-proliferation. Paper prepared for the Weapons of Mass Destruction Commission, Paper No. 41, Stockholm, Sweden.

5. Lavoy P, R Walker. 2006. Various Articles in "Conference Report: Nuclear Weapons Proliferation: 2016." Conference organized by the Center for Contemporary Conflict, U.S. Naval Postgraduate School, July 28-29, Monterey, California. Nonproliferation Review 13(3). 

Appendix A

Presence of Nuclear Activities 



\section{Appendix A - Presence of Nuclear Activities}

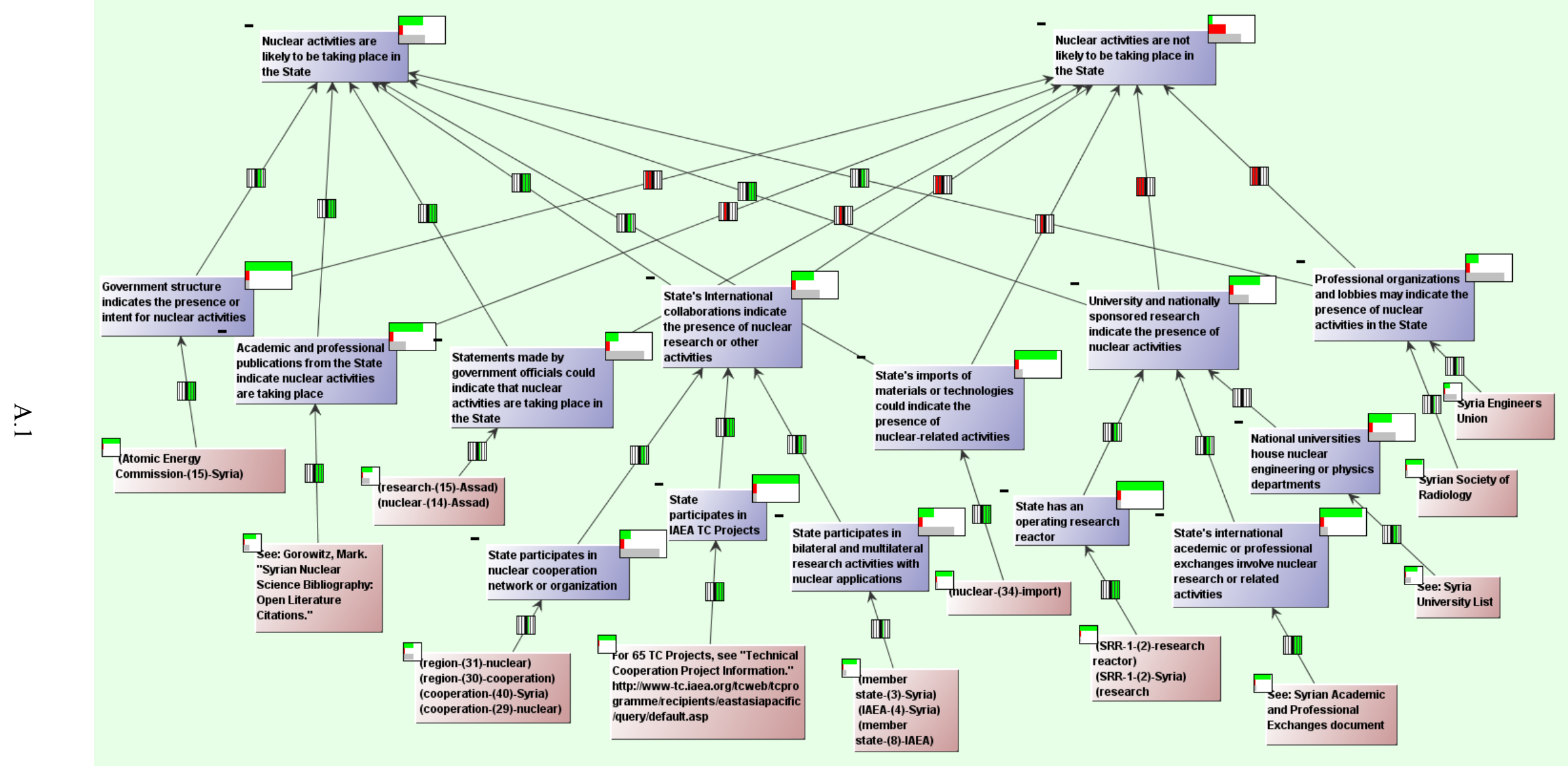





\section{Appendix B}

\section{Consistency of Nuclear Activities}





\section{Appendix B - Consistency of Nuclear Activities}

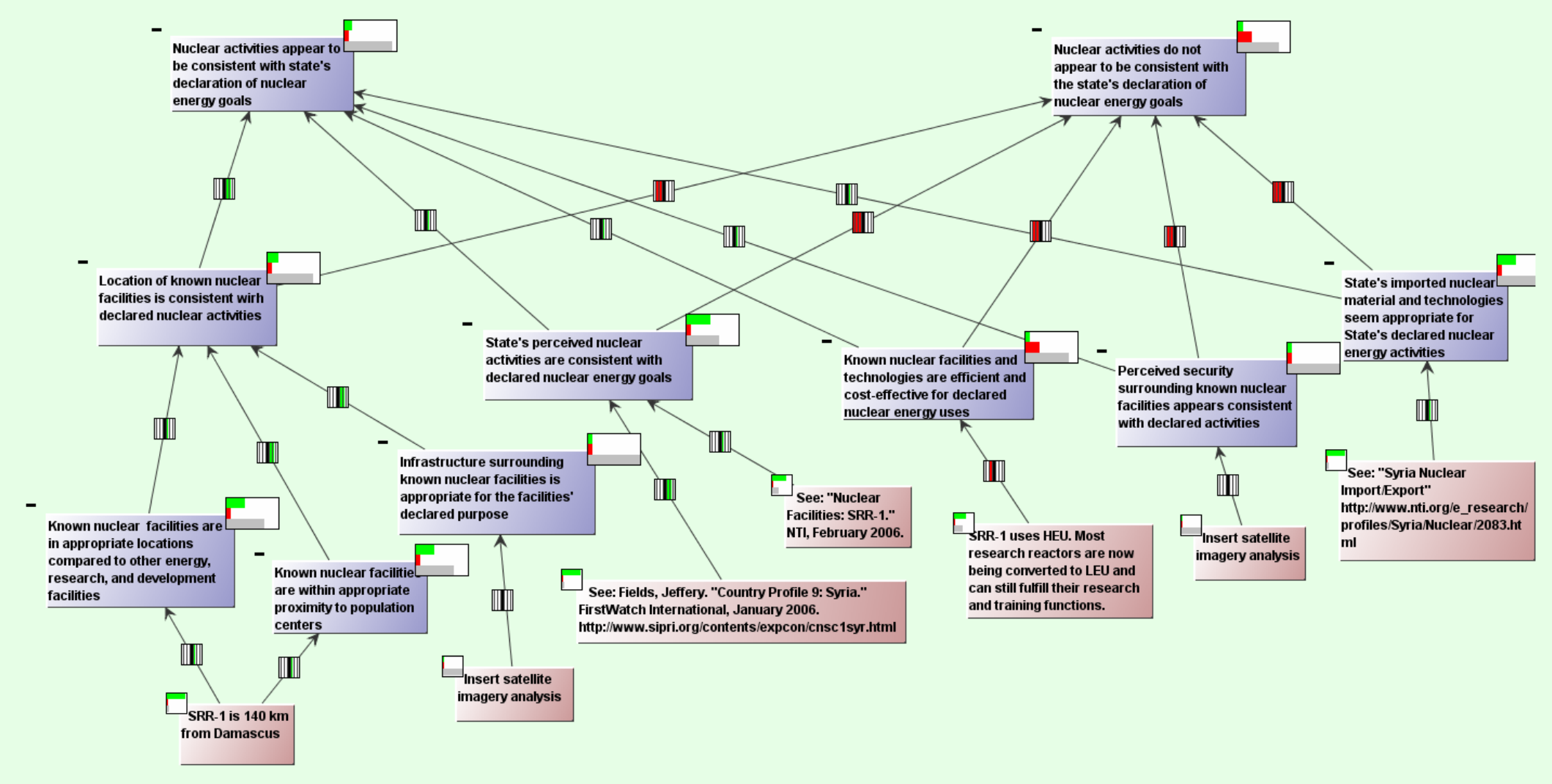



Appendix C

Geopolitical Context of Nuclear Activities 



\section{Appendix C - Geopolitical Context of Nuclear Activities}

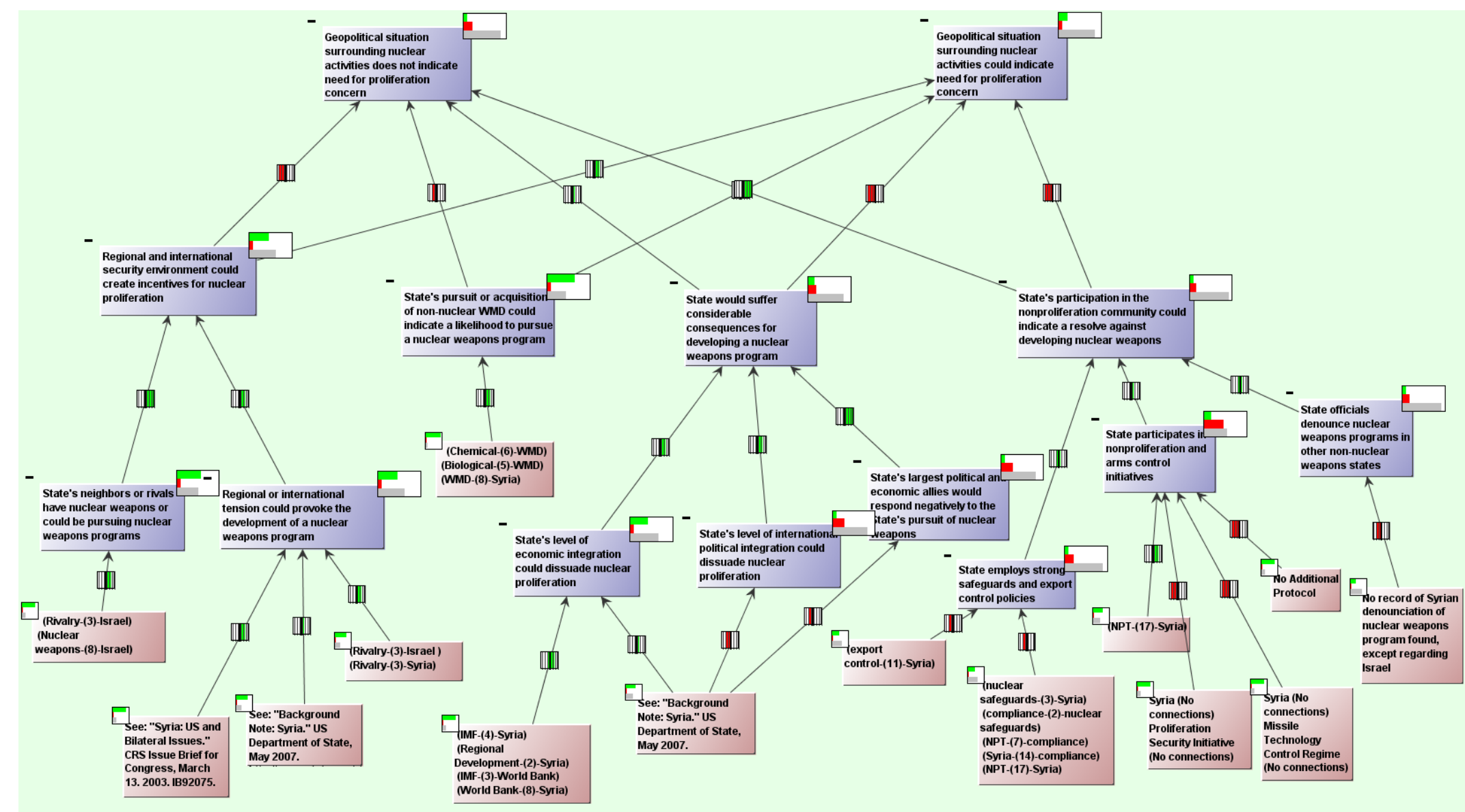



Appendix D

\section{Proof of Concept (POC) - Summary}





\section{Appendix D}

\section{Proof of Concept (POC) - Summary}

\section{D.1 Modeling Objectives}

Goals: Develop a nonproliferation model that will provide indication when states are developing nuclear technologies that are:

1) inconsistent with their stated national nuclear energy goals, and

2) taking place in a geopolitical environment that could be conductive to nuclear proliferation activities.

Expected Users: The intended user for this model was the IAEA, for use in support of the SLA for international nuclear safeguards. Other potential users could include the U.S. Government in support of energy policy decisions towards specific states or other international nonproliferation community actors.

Timing: The model was built in part as a mechanism to demonstrate the PNNL ProSPECT software tool, and to determine whether or not a state's nuclear activities and geopolitical context could be used to evaluate proliferation concerns surrounding a state's nuclear program. The model was developed and populated with evidence from Syrian test-case in FY 2008. In April 2009, PNNL was requested to provide this write-up of the Syria Proof-of-Concept model.

Criteria for Success: As statistician George E.P. Box noted in his book, "Empirical Model-Building and Response Surfaces," (1987) - "All models are wrong, but some are useful." The goal of this model development was to see if it could potentially provide useful information about the status and nature of a country's nuclear activities before it became apparent that the country was developing a nuclear weapons program. The criteria of success was that the model be able to indicate something amiss in Syria using only data prior to the 2007 Israeli destruction of a suspect nuclear facility in that country (prior to which time, the facility was virtually unknown in the unclassified world). 


\section{D.2 Comparison of Before and After the Development of Model}

\begin{tabular}{|c|c|}
\hline Prior State Before POC & New State with POC \\
\hline $\begin{array}{l}\text { Prior to the development of this model, there was } \\
\text { not a systematic way established by which to } \\
\text { evaluate a state's consistency between its declared } \\
\text { nuclear energy goals and perceived nuclear } \\
\text { activities, taken into consideration under the } \\
\text { state's geopolitical context. While this type of } \\
\text { analysis is starting to be conducted at the IAEA in } \\
\text { support of the State Evaluation Report, there is no } \\
\text { established way in which to analyze this } \\
\text { information or make conclusions regarding a } \\
\text { state's nuclear activities. }\end{array}$ & $\begin{array}{l}\text { The model provides a systematic way for analysts } \\
\text { to evaluate the consistency of a state's nuclear } \\
\text { activities with its declared nuclear energy goals } \\
\text { and within their geopolitical context. Analyzed } \\
\text { together, these factors could indicate a state's } \\
\text { propensity or motivation for nuclear proliferation. } \\
\text { The model is designed in such a way that it } \\
\text { minimizes the potential for incorporation of } \\
\text { analyst bias. The model offers: } \\
\text { 1. A systematic manner in which to evaluate } \\
\text { a country's nuclear activities, and the } \\
\text { relationship of those activities to the } \\
\text { state's declared nuclear energy plans and } \\
\text { goals. } \\
\text { 2. A systematic manner in which to evaluate } \\
\text { the geopolitical context in which their } \\
\text { nuclear activities are occurring. }\end{array}$ \\
\hline
\end{tabular}

\section{Cost Factors}

Time: Previous analytic techniques required analysts to read and remember large amounts of information from a variety of source types.
Time: By integrating the analyst's thought process into ProSPECT, the modeling environment offers an opportunity to integrate information as it is found, and easily recall and reread that same piece of information, including its source information, at a later time. The model can semi-quantitatively combine information from various sources based on the analyst's scoring of the information's importance and reliability, rather than requiring the analyst to do so (which can also introduce unintended bias). Information from sources related to the model can be recorded and stored in ProSPECT, to be reviewed and referenced at the analyst's convenience.

The IN-SPIRE data visualization tool may be used within the ProSPECT analytical environment, 


\begin{tabular}{|l|l|}
\hline $\begin{array}{l}|l| l \mid \\
\text { Infrastructure: Statistical analysis software } \\
\text { packages can cost hundreds or thousands of } \\
\text { dollars to use, and may require extensive } \\
\text { mathematical and statistical training. }\end{array}$ & $\begin{array}{l}\text { Internet search engines are also available to } \\
\text { analysts through ProSPECT's Source Space, to } \\
\text { supplement any missing information from a } \\
\text { dataset. }\end{array}$ \\
$\begin{array}{l}\text { Infrastructure: ProSPECT is a free software, } \\
\text { under development by PNNL, which requires little } \\
\text { training for its operation. It allows policy analysts } \\
\text { to describe relationships semi-qualitatively while } \\
\text { maintaining the ability to produce a robust semi- } \\
\text { quantitative result. It also has the potential to } \\
\text { incorporate more quantitative analysis, if so } \\
\text { desired by the user, by incorporating more } \\
\text { "strength" ratings that the analyst can evaluate, or } \\
\text { through probabilistic or statistical modeling that is } \\
\text { done behind the model to determine those } \\
\text { relationships. }\end{array}$ \\
\hline
\end{tabular}

\section{What worked well?}

- The ProSPECT software successfully provided the analysis environment in which to construct and evaluate a model to examine the status and nature of a state's nuclear activities.

- Information collected and analyzed in the model produced results that could have been expected-high degrees of uncertainty regarding Syria's nuclear program could have potentially served as an indicator to watch the country more closely.

\section{What did not work?}

- Evidence collection methods need to be systematized. Limited time and resources were available to collect evidence for the proof-of-concept model. Other test cases would need more time and access to more materials.

- Models would also benefit from a review of potential users to determine if they fit the users' information analysis needs.

\section{D.3 POC Experiences}

\section{Did we achieve the goals we originally set?}

The project team constructed a set of models to evaluate the status and nature of a state's nuclear activities. A test case, Syria, was evaluated to determine whether the model was able to retroactively determine the need for proliferation concern surrounding a state's nuclear activities. The test case resulted in high uncertainty. However, this test case was completed with the use of relatively little evidence. 
With more time and resources, a more robust dataset could have been collected and evaluated, leading to more conclusive results.

\section{What barriers exist for adoption of such a service? What would need to change?}

The ProSPECT software is still under development. It needs to be fully enabled and readied for commercialization before it is more widely implemented. In particular, the evidence collection environment in the Source Space needs to be expanded to offer more robust web searches in which more pages can be viewed at once, and more search engines options are available.

The model evaluating the status and nature of a state's nuclear activities, though it accomplished the goal for this specific POC, could be enhanced before further dissemination. The dissemination of a similar model to one built in this POC would require an accompanying explanation that the model attempts to analyze the world's current situation, and cannot be used as a sole source of reason for future policy decisions.

\section{D.4 Summary Justifications}

To further test the robustness of this model, other case studies should be evaluated. This could include the post-facto evaluation of historical cases of proliferant states. If the use of the model is able to help analysts and provide new or useful results to the field of nonproliferation analysis that were not evident previously, it can be considered a significant contribution.

Once further validation and verification of results has been concluded, the models could be posed as a tool that the IAEA or other users could employ for the SLA of international safeguards, or other information analysis activities with policy implications.

PNNL has the capability to submit this model to expert analysis, as well as to perform various case studies. Each case study is expected to cost approximately $\$ 30-40 \mathrm{~K}$ over a period of 6-12 months, depending on the availability of information and experts. 
Appendix E

Sources Used in Syria Model 



\section{Appendix E}

\section{Sources used in Syria model}

Activity Completion Report No. 089/88. 1988. Country: Syrian Arab Republic. Activity: Electric Power Efficiency Study. Joint UNDP/World Bank Energy Sector Management Assistance Program.

Albright A and C Hinderstein. 2004. "Uncovering the Nuclear Black Market: Working Toward Closing Gaps in the International Nonproliferation Regime." Paper prepared for the 45th Institute of Nuclear Materials Management Annual Meeting, July 18-11, Orlando, Florida. Institute of Nuclear Materials Management, Philadelphia, Pennsylvania. Accessed September 21, 2009, at http://www.isisonline.org/publications/southasia/nuclear_black_market.html.

Assyrian International News Agency. 2006. "Syria's Secret Nuclear Program and Long Term Threat." 2006. Accessed September 21, 2009, at http://www.aina.org/news/20060814102533.htm.

Bolton JR. 2003. Syria's Weapons of Mass Destruction and Missile Development Programs. Testimony before the House International Relations Committee, Subcommitte on the Middle East Central Asia. U.S. Department of State, Washington, D.C. Accessed September 22, 2009, at http://20012009.state.gov/t/us/rm/24135.htm.

Central Intelligence Agency (CIA). 2007. Unclassified Report to Congress on the Acquisition of Technology Relating to Weapons of Mass Destruction and Advanced Conventional Munitions. CIA, Langley, Virginia. Accessed September 22, 2009, at https://www.cia.gov/library/reports/archived-reports1/july_dec2003.htm.

Congress. May 15, 2007. " $110^{\text {th }}$ Congress, $1^{\text {st }}$ Session, H,R, 2332: To strengthen sanctions against the Government of Syria, to enhance multilateral commitment to address the Government of Syria's threatening policies, to establish a program to support a transition to a democratically-elected government in Syria, and for other purposes.".

Cordesman AH. 2008. Syrian Weapons of Mass Destruction: An Overview. Center for Strategic and International Studies (CSIS), Washington, D.C.

Cordesman AH. 2008. "Israel and Syria: The Military Balance and Prospects of War." Praeger Security International, published in cooperation with the Center for Strategic and International Studies (CSIS), Washington, D.C.

Cordesman A. 2005. "Proliferation of Weapons of Mass Destruction in the Middle East: The Impact on The Regional Military Balance." Center for Strategic and International Security Studies (CSIS), Washington, D.C. Accessed September 22, 2009, at http://csis.org/sites/all/modules/filefield/icons/protocons/16x16/mimetypes/application-pdf.png.

Countries of the World. 2009. "Syria Energy and Natural Resources." Accessed September 22, 2009, at http://www.photius.com/countries/syria/economy/syria_economy energy and natural r $\sim 1638 . \mathrm{html}$. 
Diab MZ. "Syria's Chemical and Biological Weapons: Assessing Capabilities and Motivations." The Nonproliferation Review, Fall Issue, 5(1):104-111.

Eisenstadt M.. 2007. "Syria's Strategic Weapons Program." Policy Watch 1288. Washington Institute for Near East Policy, Washington, D.C. Accessed September 21, 2009, at http://www.washingtoninstitute.org/print.php?template $=$ C05\&CID $=2664$

Energy Information Administration (EIA). 2008. "Syria: Electricity: Electric Power Overview.” EIA, Washington, D.C. Accessed September 22, 2009, at http://www.eia.doe.gov/emeu/cabs/Syria/Electricity.html

European Commission External Cooperation Programmes. 2008. "Country Cooperation: Syria." Accessed September 22, 2009, at http://ec.europa.eu/europeaid/index en.htm.

European Neighbourhood Policy. 2007. "European Neighbourhood and Partnership Instrument: Syrian Arab Republic. Strategy Paper: 2007-2013 and National Indicative Programme 2007- 2010.” European Commission, Brussels, Belgium. Accessed September 22, 2009, at http://ec.europa.eu/world/enp/pdf/country/enpi_csp_nip_syria_en.pdf

Executive Order 13338. 2004. Executive Order Blocking Property of Certain Persons and Prohibiting the Export of Certain Goods to Syria. Federal Register 69:26751, May 13, 2004. Reprinted by the U.S. Department of the Treasury, Office of Foreign Assets and Control (OFAC), April 26, 2006. In: Syria: What You Need to Know About U.S. Sanctions. Accessed September 22, 2009, at www.treas.gov/offices/enforcement/ofac/programs/syria/syria.pdf.

Fields J. 2006. "Country Profile 9: Syria.” Stockholm International Peace Research Institute, Stockholm, Sweden. Accessed September 22, 2009, at http://www.sipri.org/.

Ghafar M. "Radioactive Waste Management Facility in Syria." In: International Atomic Energy Agency, Vienna (Austria) International Conference on Management of Radioactive Waste from Non-power Applications - Sharing the Experience. Book of Extended Synopses, p. 86, IAEA-CN-87-79, November 59, 2001, St. Paul's Bay, Malta. International Atomic Energy Agency, Vienna, Austria.

Goodman H. 1992. “The Seeds of Nuclear Disaster.” The Jerusalem Report, p. 56.

Gorowitz M. 2005. "Syrian Nuclear Science Bibliography: Open Literature Citations." Accessed September 25, 2009, at http://www.milnet.com/Flashpoints-2006.html

Hainoun A, MK Seif Eldin, and S Almoustafa. 2006. "Analysis of the Syrian Long-Term Energy and Electricity Demand Projection Using the End-Use Methodology.” Energy Policy 34(14):1958-1970.

Accessed September 21, 2009, at http://www.sciencedirect.com/science?_ob=ArticleURL\&_udi=B6V2W-4FRPRDW-

$1 \&$ user $=2741876 \&$ rdoc $=1 \&$ fmt $=\&$ orig $=$ search \& sort $=\mathrm{d} \&$ docanchor $=\&$ view $=\mathrm{c} \&$ searchStrId $=101$ $9175748 \&$ _rerunOrigin $=$ google \& acct $=\mathrm{C} 000058656 \&$ version $=1 \&$ urlVersion $=0 \&$ userid $=2741876 \&$ $\underline{\mathrm{md} 5=\mathrm{ba} 6 \mathrm{fc} 1 \mathrm{ae} 0 \mathrm{a} 94 \mathrm{fb} 895527019 \mathrm{e} 25 \mathrm{f0} 0 \mathrm{bf} 6}$.

Hainoun A, I Othman, M Seef Eldin, and S Almostafa. 2006. "Energy and Nuclear Power Planning for Syria Covering the Time Horizon up to 2030." In: The $6^{\text {th }}$ International Conference on Nuclear Option in Countries with Small and Medium Electricity Grids, May 21-25, Dubrovnik, Croatia. INIS-HR — 06003, p. 7, International Atomic Energy Agency, Vienna, Austria. 
International Atomic Energy Agency (IAEA). 2008. The Statement of the Syrian Republic to the 52nd Session of the General Conference of the Internationmal Atomic Energy Agency, September 29-October 4, Austria, Vienna.

International Atomic Energy Agency (IAEA). 2007. "Syria - IAEA Technical Cooperation Projects." Accessed September 22, 2009, at http://wwwtc.iaea.org/tcweb/tcprogramme/recipients/eastasiapacific/query/default.asp.

International Atomic Energy Agency (IAEA). 1992. International Atomic Energy Agency, Syrian Arab Republic and China: Agreement Concerning the Transfer of a Miniature Neutron Source Reactor and Enriched Uranium (with annexes and table.) IAEA, Syrian Arab Republic, and China. February 28, No. 29081. Registered by the IAEA August 12. Accessed September 22, 2009, at http://untreaty.un.org/unts/120001_144071/2/8/00001466.pdf.

International Atomic Energy Agency Information Circular (INFCIRC). 1992. Agreement of 25 February 1992 Between the Government of the Syrian Arab Republic and the International Atomic Energy Agency for the Application of Safeguards in Connection with the Treaty on the Nonproliferation of Nuclear Weapons. INFCIRC/407. Accessed September 22, 2009, at http://www.iaea.org/Publications/Documents/Infcircs/Others/infcirc407.pdf.

International Institute for Strategic Studies. 2008. "North Korea's Ballistic Missile Program.'International Institute for Strategic Studies, Wasington, D.C.

James Martin Center for Nonproliferation Studies. 2008. Syria Profile: Biological Overview. Nuclear Threat Initiative. Accessed September 22, 2009, at www.nti.org.

James Martin Center for Nonproliferation Studies. 2008. Syria Profile: Chemical Overview. Nuclear Threat Initiative. Accessed September 22, 2009, at www.nti.org.

James Martin Center for Nonproliferation Studies. 2008. Syria Profile: Missile Capabilities Capabilities Overview. Nuclear Threat Initiative. Accessed September 22, 2009, at http://www.nti.org/e research/profiles/Syria/Missile/4126.html.

James Martin Center for Nonproliferation Studies. 2007. China's Missile Exports and Assistance to Syria. Nuclear Threat Initiative. Accessed September 22, 2009, at http://www.nti.org/db/china/msyrpos.htm.

James Martin Center for Nonproliferation Studies. 2007. Syria Profile: Nuclear Chronology 1963-2003. Nuclear Threat Initiative. Accessed September 22, 2009, at http://www.nti.org/e_research/profiles/Syria/Nuclear/2079.htmll.

James Martin Center for Nonproliferation Studies. 2006. Syria Profile: Missile Chronology 1988-1999. Nuclear Threat Initiative. Accessed September 22, 2009, at. http://www.nti.org/e research/profiles/Syria/Missile/3960.html.

James Martin Center for Nonproliferation Studies. 2006. Syria Profile: Syria Missile Import/Export. Nuclear Threat Initiative. Accessed September 22, 2009, at. www.nti.org

James Martin Center for Nonproliferation Studies. 2006. "Syria: Weapons of Mass Destruction Capabilities and Programs." Monterey, California. Accessed September 22, 2009, at http://cns.miis.edu/wmdme/syria.htm. 
James Martin Center for Nonproliferation Studies. 2005. Syria Profile: Nuclear Imports. Nuclear Threat Initiative. Accessed September 22, 2009, at

http://www.nti.org/e_research/profiles/Syria/Nuclear/2083.html.

Jenkins G. 2008. "Syria Proposes Nuclear Cooperation with Turney." Eurasia Daily Monitor, 5(114).

Accessed September 22, 2009, at

http://www.jamestown.org/programs/edm/single/?tx ttnews[tt news] $=33723 \& t x$ ttnews[backPid] $=166 \&$

$\underline{\text { no } \text { cache }=1}$ ?.

Jerusalem Post. December 20, 2007. "Assad says in 2001 he rejected offer from Pakistani smuggler to buy nukes. Sarkozy: I have 'reached the end of the road' with Syrian Leader."

Kass L. 2005. "Syria After Lebanon: The Growing Syria Missile Threat.” Middle East Quarterly. Fall Issue, Volume XII, Number 4. Accessed September 22, 2009, at http://www.meforum.org/755/syria-afterlebanon-the-growing-syrian-missile.

Kattouf T, MN Kessler, H Melhem, and M Jouejati. 2007. "Symposium: When We Meet with Syria, What Should We Say? What Should we hope to Hear?" Middle East Policy, Summer, XIV(2). Accessed September 22, 2009, at http://www.mepc.org/forums_chcs/48.asp.

Khamis I and A Hainoun, 1998. "Market Potential of Small and Medium-Power Reactors in Syria." In: Introduction of Small and Medium Reactors in Developing Countries. Proceedings of Two Advisory Group Meetings, October 23-27, 1995 and September 3-6, 1996. Rabat, Morocco and Tunis, Tunisia. IAEA-TECDOC-909, pp. 225-228. International Atomic Energy Agency, Vienna, Austria.

Kiernan S. 1995. "Argentina Reaches Agreement with Syria on Nuclear Materials." Jewish Telegraphic Agency, New York, p. 6.

Lesch DW. 1999. "Is Syria Ready for Peace? Obstacles to Integration in the Global Economy." Middle East Policy VI(3). Accessed September 22, 2009, at http://www.mepc.org/journal_vol6/9902_lesch.asp.

Magnus N, A Lindblad, A Norqvist, B Sandström, L Waldenström. 2004. Syria and WMD Incentives and Capabilities. FOI-R-1290-SE, Swedish Defence Research Agency, Stockholm, Sweden. Accessed September 22, 2009, at http://www2.foi.se/rapp/foir1290.pdf.

Miller G. 2006. "The World; N. Korea Threat Lies in Nuclear Sales; U.S. Intelligence Officials and Weapons Experts say the Possible Export of Atomic Material and Know-how is a Greater Concern than an Attack." Los Angeles Times. October 21 Issue, p. A5.

Molling C and G Neuneck. 2003. "Military Capabilities in the Near and Middle East." International Network of Engineers and Scientists Against Proliferation. Bulletin 21 - Non-proliferation and Preventive War. Accessed September 22, 2009, at http://www.inesap.org/sites/default/files/inesap_old/bulletin21/bul21art05.htm.

Moore M. 2005. "In Israel, Putin Defends Syria, Iran Deals; Russian President's Visit Seen as Milestone in Relations, Despite Disagreements." The Washington Post, p. A18. Accessed September 22, 2009, at http://www.washingtonpost.com/wp-dyn/content/article/2005/04/28/AR2005042800562_pf.html.

Nanay J. 2001. "Turkey's Relations with Iran, Syria, Israel, and Russia, 1991-2000: The Kurdish and Islamist Questions." Middle East Policy. 8(3):179. Accessed September 21, 2009, at http://findarticles.com/p/articles/mi_qa5400/is_200109/ai_n21476842/?tag=rel.res1. 
Naylor H. 2007. "Syrians Tired of Energy Ills Doubt the West is to Blame." The New York Times, August 15 Issue, p. A8.

Office of Foreign Assets Control (OFAC). 2005. "Recent OFAC Actions." 2009. U.S. Department of the Treasury, Washington, D.C. Accessed September 21, 2009, at http://www.treas.gov/offices/enforcement/ofac/actions/index.shtml.

Office of the Director of National Intelligence. 2004. Unclassified Report to Congress on the Acquisition of Technology Relating to Weapons of Mass Destruction and Advanced Conventional Munitions, 1 January-21 December 2004. Released May 2006 by the Office of the Director of National Intelligence. Accessed September 22, 2009, at http://www.GlobalSecurity.org.

Olson R. 1997. "Turkey-Syria Relations Since the Gulf War: Kurds and Water." Middle East Policy. 5(2):168. Acessed September 21, 2009, at http://www.encyclopedia.com/doc/1G1-19496514.html.

Othman I.. 2001. "National Infrastructure for Detecting, Controlling and Monitoring Radioactive Materials." In: International Conference on Security of Material. Measures to Prevent, Intercept and Respond toIillicit Uses of Nuclear Material and Radioactive Sources, May 7-11, 2001, Stockholm, Sweden. IAEA-CN-86-52, p. 93, International Atomic Energy Agency, Vienna, Austria.

Prados, AB. May 13, 2003. "Syria: U.S. Relations and Bilateral Issues." CRS Issue Brief for Congress. Order Code IB92075. Accessed September 25, 2009, at http://opencrs.com/document/IB92075/2003-05$\underline{13 /}$

Salem P, D Levy, and M Ottaway (Panelists). 2008. "Can Syria and Israel be Serious About Peace? And What Should the U.S. Do About it?" Carnegie Endowment for International Peace, Washington, D.C. Accessed September 22, 2009, at http://carnegieendowment.org/events/?fa=eventDetail\&id=1182\&prog=zgp\&proj=znpp.

Reuters. July 13, 2008. "Report: Turkey and Syria consider joint nuclear energy project." Accessed September 22, 2009, at http://www.haaretz.com/hasen/spages/992615.html.

Reuters. February 18, 2003. "Russia eyes Iran, Syria as arms sales rise in 2002.”. Accessed September 22, 2009, at http://www.cdi.org/Russia/johnson/7067-12.cfm.

Samore G. 2007. “Samore: A Syria-North Korea Nuclear Relationship?” B Gwertzman, Editor. Council on Foreign Relations, Washington D.C. Accessed September 22, 2009, at http://www.cfr.org/publication/14250/.

Segal N. 1995. "Argentina Will Not Sell Nuclear Reactor to Syria.” Jewish Telegraphic Agency, New York: July 24 Issue, p. 3.

Sharp JM. 2008. Syria: Background and U.S. Relations. Order Code RL33487, Congressional Research Service, Washington, D.C. Accessed September 22, 2009, at http://fpc.state.gov/documents/organization/105180.pdf.

Shoham D. 2002. “Guile, Gas and Germs: Syria's Ultimate Weapons.” Middle East Quarterly. Summer Issue, Volume IX, Number 3. Accessed September 22, 2009, at http://www.meforum.org/493/guile-gasand-germs-syrias-ultimate-weapons. 
Shohan D. 2002. "Poisoned Missiles: Syria's Doomsday Deterrent." Middle East Quarterly, Fall Issue, IX:4).

Stockholm International Peace Research Institute (SIPRI). 2004. "Syria Country Profile." SIPRI, Stockholm, Sweden. Accessed September 22, 2009, at www.sipri.org.

Stratfor Global Intelligence. 2008. Syria: A Place in the Middle Eastern Energy Network. Stratfor Global Intelligence, Austin, Texas. Accessed September 22, 2009, at http://www.stratfor.com/analysis/syria place middle eastern energy network.

Sullivan P. 1999. "Globalization: Trade and Investment in Egypt, Jordan, and Syria Since 1980 Statistical Data Included.” Arab Studies Quarterly, Summer Issue 21(3):35-72.

Syrian Arab Republic, Ministry of Economy and Trade. 2008. "Syrian European Partnership.”

Syrian Arab Republic, Ministry of Electricity, Supply Side Efficiency and Energy Conservation and Planning Project. 2005. Identification of National Energy Policies and Energy Access in Syria. Accessed September 22, 2009, at http://webfea.fea.aub.edu.lb/fea/research/erg/web/Policy\%20Paper\%20Syria.pdf.

The Saban Center at Brookings. 2005. "Inheriting Syria: Bashar's Trial by Fire.” The Brookings Institution, Washington, D.C. Accessed September 22, 2009, at http://www.brookings.edu/ /media/Files/events/2005/0425middle\%20east/20050425.pdf.

United National Development Programme (UNDP). 2008. "Syria.” Accessed September 22, 2009, at http://www.undp.org.sy/.

United Nations Security Council (UNSC). 2004. "National Report of the Syrian Arab Republic Pursuant to Security Council Resolution 1540." S/AC.44/2004/(02)/70. UNSC, New York. Accessed September 22, 2009, at http://daccessdds.un.org/doc/UNDOC/GEN/N04/661/61/PDF/N0466161.pdf?OpenElement.

United States Department of State. May 2007. "Background Note: Syria.” Accessed September 25, 2009, at http://www.state.gov/r/pa/ei/bgn/3580.htm

White House. Office of the Press Secretary. 2004. Fact Sheet: Implementing the Syria Accountability and Lebanese Sovereignty Restoration Act of 2003. White House Press Release, Washington, D.C. Accessed September 22, 2009, at http://merln.ndu.edu/archivepdf/syria/WH/20040511-7.pdf.

Wisconsin Project on Nuclear Arms Control. 1997. "Syria's Chemical Weapons - 1997" The Risk Report, 3(6), November-December 1997. Accessed September 22, 2009, at http://www.wisconsinproject.org/countries/syria/chem.html.

Zunes S. 2007. "Washington Takes Aim at Syria." Foreign Policy in Focus. May 2 Issue. 


\section{Distribution}

No. of

Copies

\# Name

Organization

Address

City, State and ZIP Code

\# Organization

Address

City, State and ZIP Code

Name

Name

Name

Name

Name (\#)

\# Name

Organization

Address

City, State and ZIP Code
No. of

Copies

\section{\# Foreign Distribution}

\# Name

Organization

Address

Address line 2

COUNTRY

\# Local Distribution

Pacific Northwest National Laboratory

Name

Name

Name

Name

Name
Mailstop

Mailstop

Mailstop

Mailstop

(PDF) 




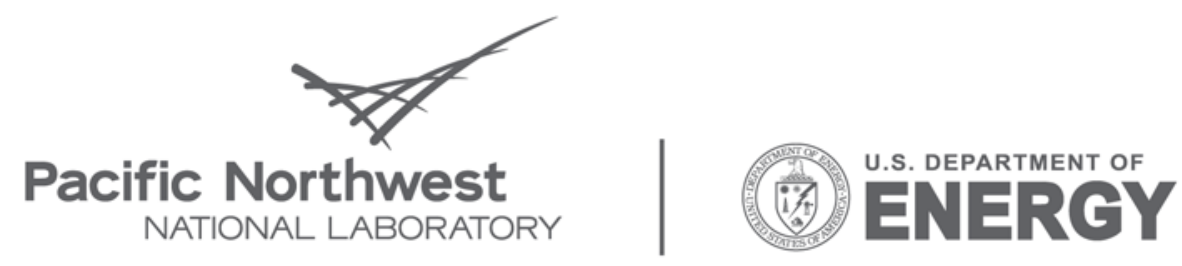

Proudly Operated by Battelle Since 1965

902 Battelle Boulevard

P.O. Box 999

Richland, WA 99352

1-888-375-PNNL (7665)

www.pnl.gov 